\title{
The Impact of the COVID-19 Pandemic on Musical Societies in the Valencian Region, Spain
}

\author{
María Ángeles Carabal-Montagud (D), Guillem Escorihuela-Carbonell $\mathbb{D}^{\circ}$, \\ Virginia Santamarina-Campos $\mathbb{D}$, and Javier Pérez-Catalá
}

\section{Musical Societies in the Valencian Region}

Musical societies in the Valencian Region are complex structures that include symphonic bands, music schools, choirs and orchestras. They are responsible for the transmission of knowledge and offer comprehensive training based on an associationtype organisation. Some of them have a main band and another youth or children's band.

According to data from the Valencian Region Federation of Musical Societies, there are over 1,100 bands, over 600 educational centres, over 40,000 musicians, 60,000 students and 200,000 members in the Valencian Region's musical societies (Las Provincias, 2020).

The social fabric that is generated by these societies is very extensive, given that their legacy is part of local culture and heritage, and they are linked to the creative and cultural industries. Not only are they centres where knowledge is imparted, but they also write methods and develop musical learning computer programmes for their schools, thus generating new ICT learning methodologies.

\footnotetext{
M. Á. Carabal-Montagud $(\varangle)$. V. Santamarina-Campos

Universitat Politècnica de València, Valencia, Spain

e-mail: macamon@crbc.upv.es

V. Santamarina-Campos

e-mail: virsanca@crbc.upv.es

G. Escorihuela-Carbonell

ISEACV, Institut Superior D’Ensenyances Artístiques de La Comunitat Valenciana, Valencia, Spain

e-mail: gescorihuela@florida-uni.es

J. Pérez-Catalá

Centre Artístic Musical, Moncada, Asociación Musical, Rocafort and Societat Artística, Alginet, Spain 


\subsection{Historical Introduction to Musical Societies}

The origins of these bands in the Valencian Region lie in religion, recreational centres, casinos and military institutions (Almeria, 2014).

The first written evidence of the existence of national military bands appeared in 1792 (Vell, 2014). Some of the bands in the region were created using instruments from the First Carlist War period, between 1833 and 1840. An example is the Banda La Lira de Titaguas (Image 1), founded in 1840, which revealed that "when the government forces arrived to reduce the Carlist forces, they abandoned in their flight the band's musical instruments that they were carrying. These were picked up by a neighbour called Blas Portolés, a potter and violinist, who took advantage of this circumstance to found a small band in the town of Titaguas" (Exm. Ayuntamiento de Titaguas, 2020).

The military bands disseminated knowledge by giving music classes throughout the nineteenth and twentieth centuries, and were the first to combine musical education with the band function. Ecclesiastical music chapels were also a source of transmission and music teaching in the nineteenth century, along with private music teaching centres for the civilian population (Fernández Vicedo, 2010).

There have been bands in the Valencian Region for over two centuries. These include the Banda de Muro, created in 1801 (Unió Musical Muro, 2020), and the Banda Primitiva de Llíria, founded in 1819 (Ateneu Musical i d’Ensenyament, 2019).

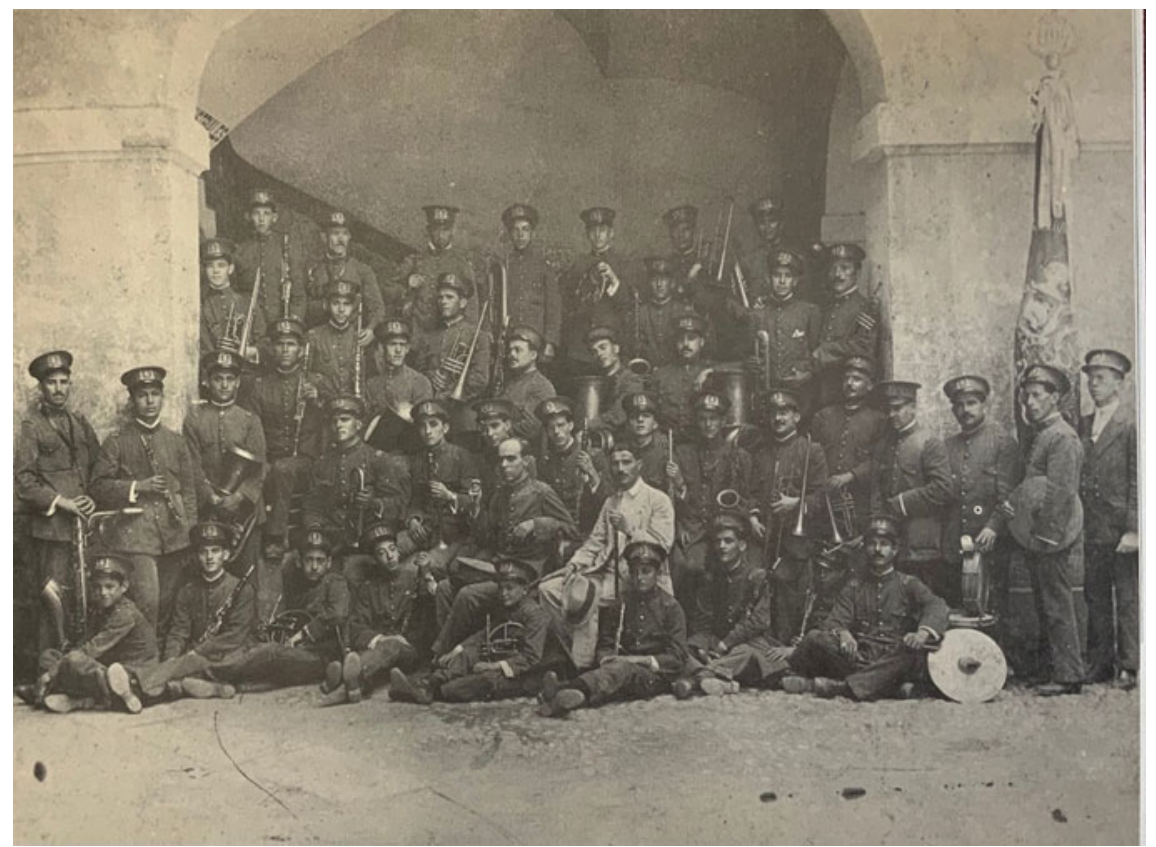

Image 1 Sueca municipal band founded in 1847, in a photo from 1921 (Source Ferri Chulio [1983]) 
According to Ruiz de Lihory in La música en Valencia, Diccionario biográfico y crítico, at the end of the nineteenth and beginning of the twentieth centuries, a number of bands were founded in villages near the city of Valencia, led by the maestro José Balanzá Herrera. "He organized and directed several municipal bands in different towns, such as Silla, Alcacer, Picassent and others, leaving in all of them a multitude of pieces expressly written [...]" (Ruiz de Lihory, 1903). Since then, the number of bands has grown constantly, with groups being formed throughout the twentieth century (Image 2), such as the Banda de Torrefiel, in 1913 (Centro Instructivo Musical Banda de Torrefiel, 2020) and the Unió Musical de Albaida "l’Aranya", in 1923 (Unió Músical D’ Albaida "L'Aranya", 2020).

Some of today's musical societies are a merger of older bands. An example is the Union Musical de Sax, founded in 1929, which joined forces with the Sociedad Musical la Primitiva and the Banda de Música La Moderna, both from the nineteenth century.

There are also cases of old bands that disappeared and have been re-founded, such as "Sueños de Artista" in Almedijar, founded in 1912 and re-founded in 2012 (Unión Musical "Sueños de Artista", 2020), and the Unión Musical de Caudiel, which was founded in 1891, disappeared in 1954 and returned in 1991 (InfoPalancia, 2016).

During the twenty-first century, newly created musical societies have continued to appear, such as the Banda Tendetes in the city of Valencia, founded in 2000 (Centro Musical Tendetes, 2020), and the Musical Centre Històric de València, in 2016.

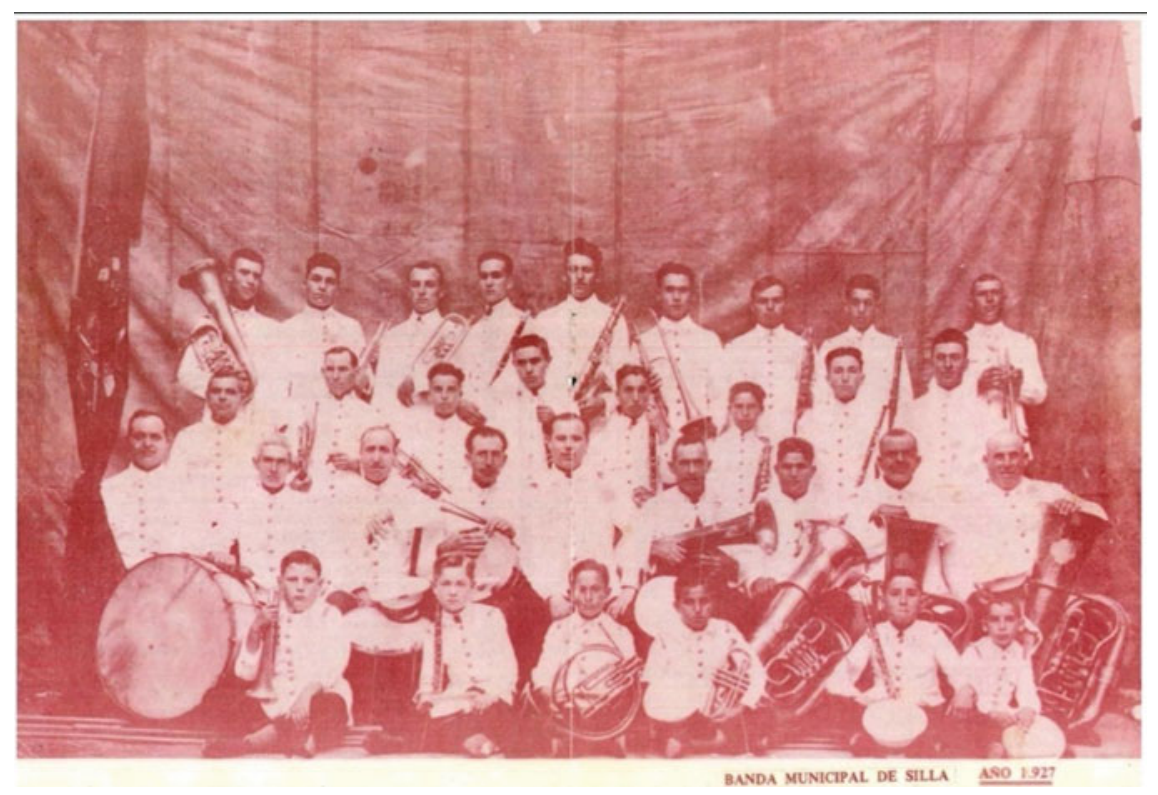

Image. 2 Silla municipal band, in 1927 (Source Les Bandes de Música de Silla [2006]) 
The bands' association model is based on that of the Federacio de Societats Musicals de la Comunitat Valenciana (FSMCV). The Valencian Region Federation of Musical Societies was created in 1968 whilst the Valencian Music Law was approved in 1988, to "promote the development of musical societies and the evolution of their music schools" (Almeria, 2014). According to its own statement, the FSMCV defines as itself "a non-profit entity whose objective is to unite its member associations in order to promote, disseminate and dignify the hobby, teaching and practice of music, by promoting the associations and providing civil society with means of development and cultural organisation" (FSMCV, 2020). Furthermore, it represents and defends the interests of musical societies in their relations with public and private institutions, and it requests, channels and advises them on the financial aid available and the subsidies granted by national and international institutions, and contributes to their cultural and educational work.

\subsection{Musical Society Functions}

Musical societies are self-governing. They follow an association-based model and must be sustainable, build trust and persist over time. They must ensure the management and effectiveness of resources (employees and volunteers), creativity and culture; training and promotion of musical talent (transmission of knowledge), social dynamics and a reflection of the community, and innovation and connection with the world and the impact derived from changes (III General Congrés de Societats Musicals de la Comunitat Valenciana, 2013). The adaptability of these entities to events has been very surprising, as the recent COVID-19 pandemic has shown.

One of the main functions of musical societies is the conservation and continuity of the documentary heritage of their bands, which is one of the symbols of Valencian identity.

Musical societies are funded by membership fees, the sale of lottery tickets and other types of subsidies given by local and regional government, such as contracts and collaboration agreements to perform concerts, musical exchanges with other cities, musical performances at folk festivals and other contracts for musical performances such as the Fallas and Moors and Christians festivals. Another source of income is provided by subsidies for music schools, which are granted by the Valencian Regional Government's General Directorate for Vocational and Special Training. These are largely used to pay for the social security costs of the teaching staff in these centres.

In addition, there are other European subsidies and grants available, and taking part in competitions and contests also brings economic rewards. The Valencia International Band Contest, which has been held since 1886, is a good example. Although the name, categories and its functioning have changed over time, in 2019 it was celebrated for the 133rd time. Over the years, thousands of bands from around the world have participated in the event (Valencia International Band Contest, 2020). Other musical competitions attended by Valencian bands to obtain financial and prestigious prizes include the Alicante (1971), Valencia (1976) and Castellon (1977) 


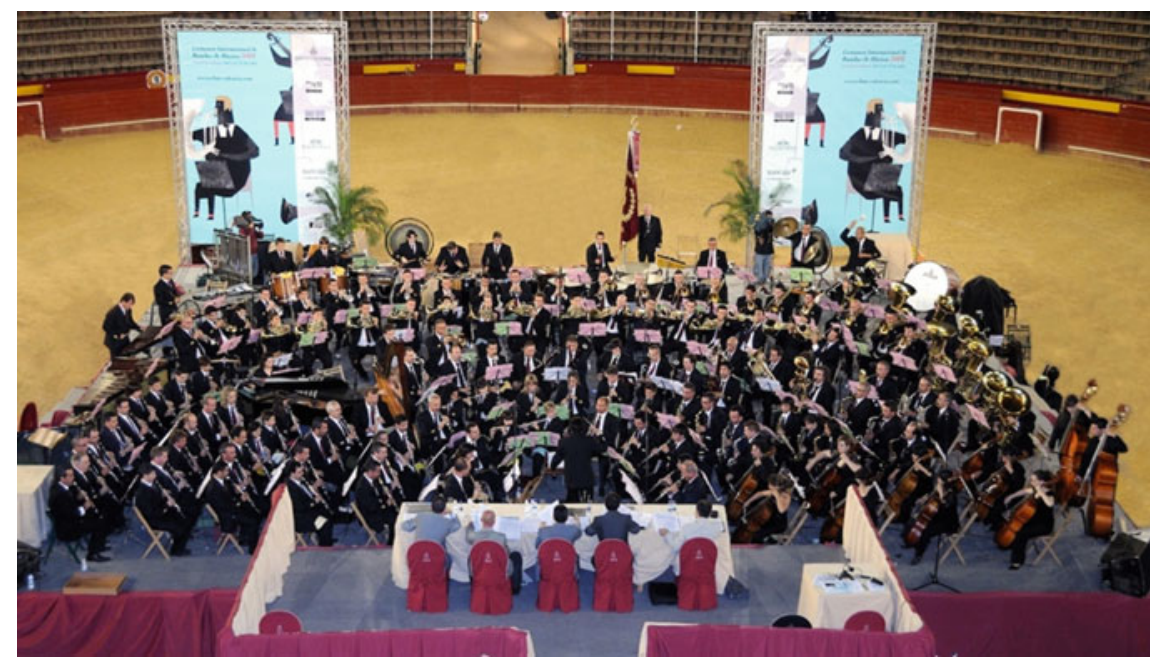

Image 3 Valencia International Band Contest, 2005 (Source Ateneu Musical de Cullera [2020])

provincial band competitions, the Cullera National Band Contest (1947), the Villa de Altea International Band Contest (1949) in Spain and the World Music Contest in Kerkrade (1951) in the Netherlands (Image 3).

\subsection{Musical Societies Declared as Cultural Heritage}

In 1998, the Valencian Music Law was created to protect musical societies. This law includes measures to promote music and its learning at all levels, so as to promote its dissemination, by creating the means and conditions for the cultural and musical development of civil society. The importance of these bands is reflected in the fact that the Valencia Provincial Council has a deputy delegate in charge of bands, being the only Spanish territory to have this position.

The Valencian Region's musical societies were declared as an Asset of Intangible Cultural Interest in 2018, in Valencian Government Decree 68/2018 of 25th May by the Regional Ministry of Education, Research, Culture and Sports (Generalitat Valenciana, 2018). This declaration is linked to the popular Valencian musical tradition, materialised by the musical societies, as transmitters of intangible heritage.

On 30 March 2021, the Spanish Government declared musical societies in the Valencian Region as a Representative Manifestation of Intangible Cultural Heritage in Spain, taking into account their cultural, educational and social relevance. This declaration protects musical societies, as it safeguards their heritage and ensures their permanence over time, given that this protection is associated with greater financial aid, which will help to alleviate the negative impact caused by the pandemic. 


\subsection{Musical Societies by Areas}

Currently, according to FSMCV data, the Valencian Federations has 557 registered musical societies with 200,000 members (FSMCV, 2020). In addition to this data, the bands are divided into a total of 30 geographical areas (Fig. 1).

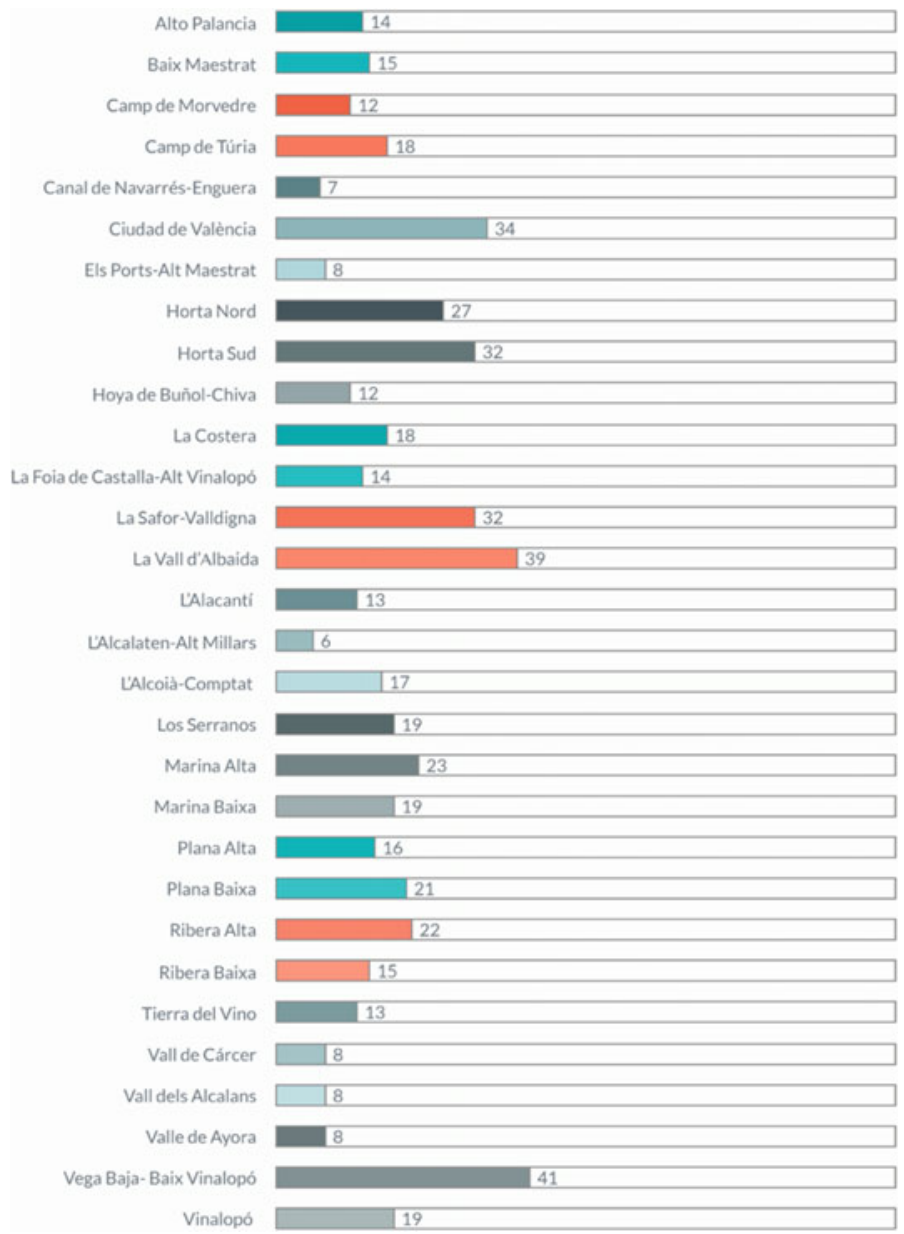

Fig. 1 Musical societies by districts (Source Authors' own) 


\section{The Impact of the COVID-19 Pandemic on Musical Societies}

\subsection{Current Situation}

The pandemic has had a huge impact on the heritage linked to public performances and social relations, given that all the intangible cultural events as well as the musical performances associated with them have all been suspended.

Due to the global pandemic, musical society bands stopped functioning during the state of alarm in Spain, declared on 14 March 2020 by Royal Decree 463/2020 (BOE, 2020) and extended until 21 June 2020, by articles 1 and 2 of Royal Decree $555 / 2020$ on 5 June (BOE, 2020).

During this time, teaching activities moved to an online format overnight in response to safety measures which initially prevented citizens from leaving their homes, and later on required adaptation to new safety regulations to prevent the spread of COVID-19. The musical societies responded to both circumstances by trying to continue the group rehearsals for their bands, choirs, orchestras, music schools and other groups.

\subsection{Ethnographic Study of the Impact of the COVID-19}

A survey was carried out among registered musical societies in the Valencian Region to assess the extent to which they were affected by the pandemic from March 2020 onwards. The survey was answered by more than $50 \%$ of the musical societies. At first, activities were restricted due to the initial lockdown period between March and June 2020, though extensive restrictions remained in place after the first state of alarm. Given this situation, and in their effort to maintain their economic and social activities, these societies had to implement complex prevention measures to ensure safety during rehearsals and had to contemplate the cancellation of acts, events and performances.

The survey was carried out using the Google Forms ${ }^{\circledR}$ tool and centred on the impact the pandemic has had on musical societies' social, economic, artistic and teaching dimensions and on their future. It was sent via email during the month of October 2020 to all musical societies and was also publicised through other social networks.

The surveys were answered anonymously by the musical societies in the 30 geographical areas mentioned above. By area (Fig. 2), 1'Horta Sud (14.3\%) had the highest number of respondents, followed by the Vall d'Albaida (8.5\%), 1'Horta Nord $(7.6 \%)$ and Ciutat de València $(7.2 \%)$.

In terms of the social dimension, the survey aimed to assess losses in the societies' social fabric, in terms of members, by compiling the musical actions they carried out during lockdown and their general assessment of the pandemic's social impact. 


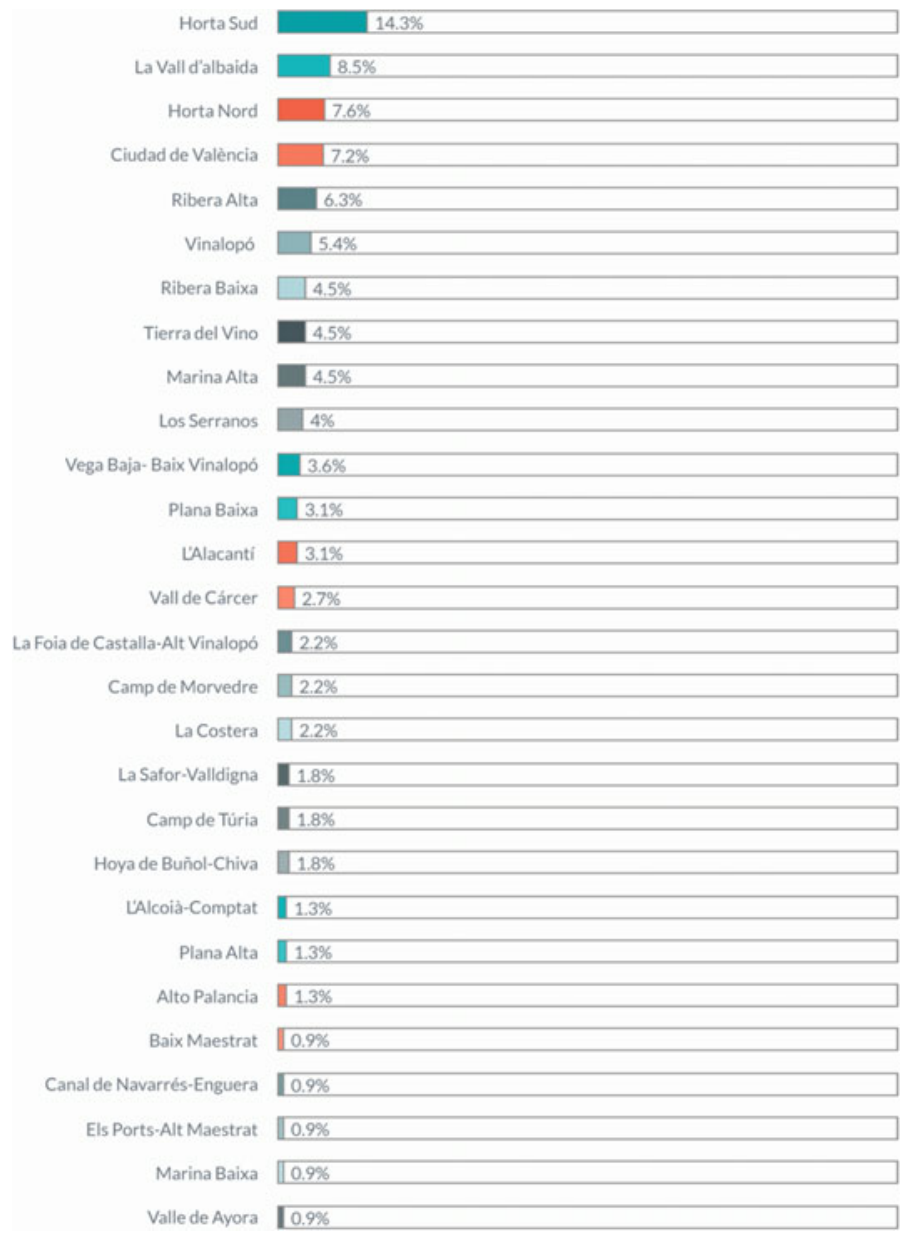

Fig. 2 Survey participation by areas (Source Authors' own)

The results obtained in terms of how the social sphere of these musical societies was affected by the pandemic showed responses on a scale of $1-5$, in which 1 was the lowest impact and 5 was the highest. The scores were as follows: $2.7 \%$ rated the impact suffered as low (score 1); 6.3\% rated the impact of the pandemic as moderate (score 2); $20.5 \%$ rated a medium impact (score 3 ); $37.1 \%$ rated the impact as high (4 on the scale); and $33.5 \%$ considered it as very high, with a 5 . Accordingly, $70.6 \%$ of musical societies valued the impact of the pandemic in social terms as high or very high (Fig. 3).

Regarding the decline of the social fabric, in terms of number of members after the state of alarm and the suspension of activities, $45.5 \%$ declared that they had not lost any members during this period, whilst $54.5 \%$ confirmed the opposite. This fact is linked to the financial situation of these musical societies, since fewer members mean 
Fig. 3 Impact of the pandemic on musical societies in the social sphere

1 $2.7 \%$ (Source Authors' own)
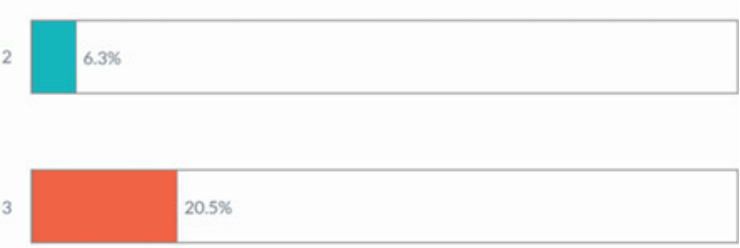

4

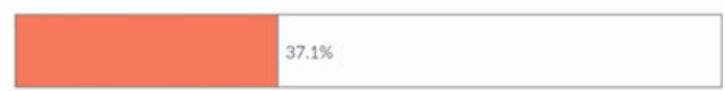

5 $33.5 \%$

fewer membership fees, producing economic losses that had not been contemplated at the beginning of 2020 .

The musical societies performed during lockdown and when the restrictions were alleviated, taking into account health recommendations and legal regulations.

During lockdown, performances were given by individual musicians from their homes and were shared through social networks, in an attempt to lift the spirits of the population. In many cases, there were several musicians in the same family and they played together.

$89.3 \%$ of musical societies declared that individual members had given some kind of individual performance. $84.2 \%$ of the groups went out on their balconies to play instruments individually. There were calls through social networks to play the same music which could be heard at the same time, simulating a parade. Parades are a deeply rooted tradition for bands, together with playing musical compositions specifically created for intangible cultural events, like the highly popular, traditional local festivities like the Fallas in Valencia, the festivities of La Magdalena in Castellon and the Fogueres de Sant Joan in Alicante-each of them representing the individual character of their communities.

An example of this took place on 19 March, St. Joseph's Day, which is the day of the patron saint of the city of Valencia. This date is when the Fallas figures are burnt in an act known as the Cremà. The Fallas festival was registered in 2016 on the Representative List of the Intangible Cultural Heritage of Humanity (UNESCO, 2016). On this symbolic day for Valencians, a call to action was put out through social networks to all musicians to play the songs Paquito el Chocolatero and Amparito Roca in unison, on their balconies and from their windows at midday. This initiative 


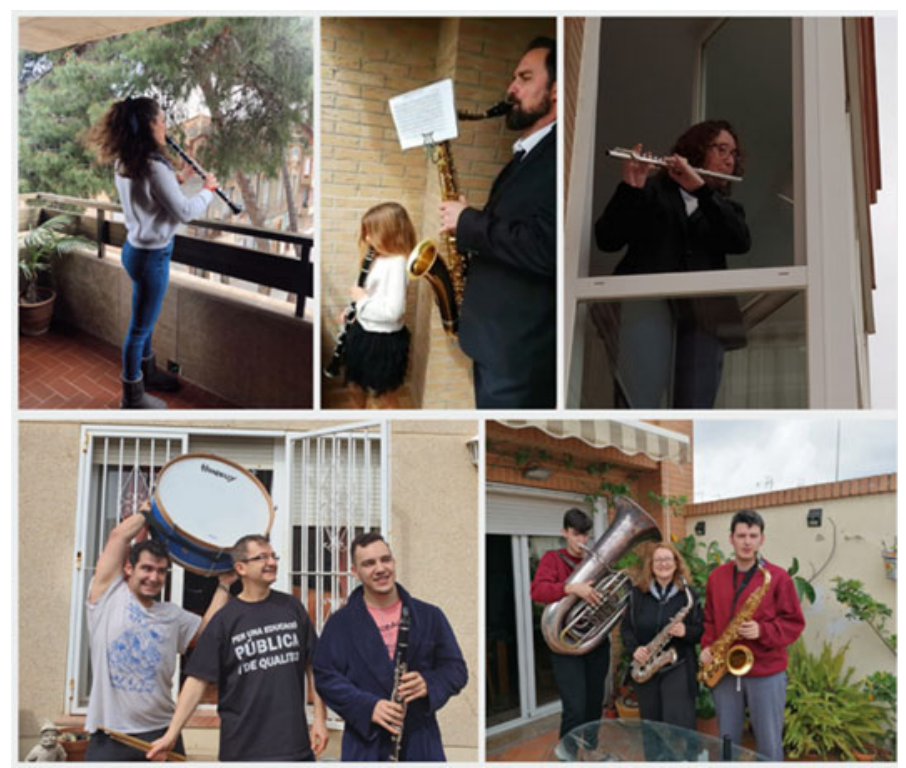

Image 4 Balcony music in March 2020 (Source Agrupación Musical Los Silos de Burjassot [2020])

was organised by FSMCV, which promoted a campaign with the hashtag \#FestivalDelsBalcons and the slogan "because we are the land of music, we are going to hit the highest note" (Nuestras Bandas de Música, 2020) (Images 4 and 5).

$16.8 \%$ of the societies streamed concerts, broadcasting them on social networks and other online platforms. Each musician recorded the concert at home, and then, these recordings were put together. Some of them recorded their local town anthem from their homes, and these were later edited and published. These music-based initiatives managed to strengthen public spirit, which had been severely hit by the pandemic, given the fact that the population had been isolated under lockdown, causing social rupture.

83.2\% published videos on social media with individual home recordings, which were later edited and put together. The difficulty of combining tempos and music in this scenario was particularly noteworthy. $59.4 \%$ of societies published images on networks. Some of their activities, such as making masks for people in need, which were not directly linked to music broadcasts, had a marked social character.

In the post-lockdown period, musical activities continued in other ways, such as parades with the required safety distance between the musicians. For example, the Potríes band marched using specific masks whilst they played (PLÁ, 2020) (Image 6).

These masks were designed, manufactured and marketed by the Sanimusic ${ }^{\circledR}$ brand, which specialises in health and safety for rehearsals and musical events to prevent the risk of contagion caused by COVID-19, under the slogan "we work to keep our culture healthy". The firm sells masks, disinfectant for instruments, 
Image 5 Campaign promoted and organised by FSMCV (Source Nuestras Bandas de Música [2020])
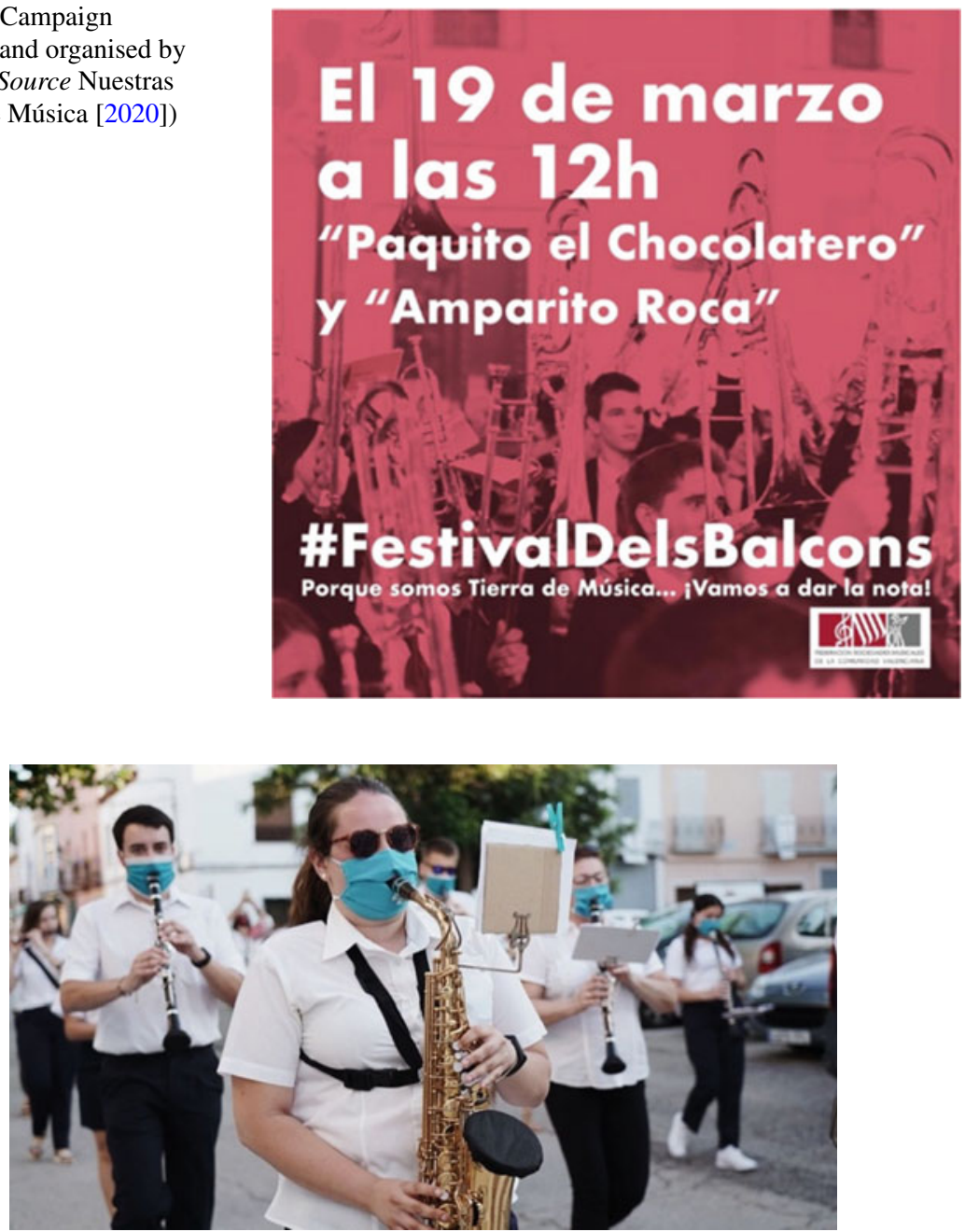

Image 6 Potries band parading with masks (Source Niusdiario [2020])

protection screens and other products. Profits from this venture will go to the Partitura y Territorio foundation (Sanimusic, 2020).

Other activities were carried out outdoors or indoors with limited capacity and with COVID-19 safety measures. Some of them were given financial help from the Valencia Provincial Council, such as the Excellent Band Concerts. Federationmember band exchanges were another of the activities carried out after lockdown. These activities are subsidised by the FSMCV, so the premise was to perform them without inviting another musical society, as though it were a normal concert. 
Fig. 4 Economic impact of the pandemic on musical societies (Source Authors' own)
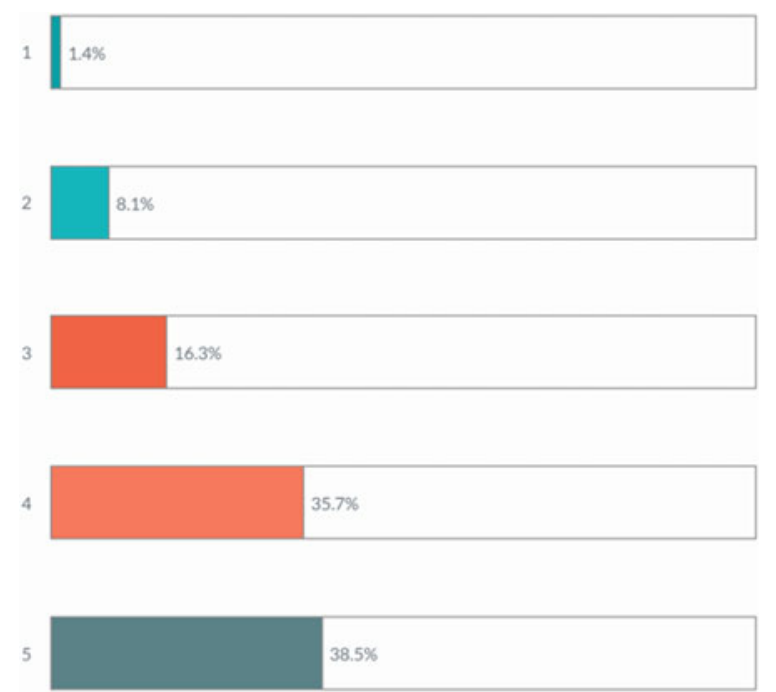

The economic impact of the pandemic on musical societies was also analysed in the survey. The scores ranged from 1 to 5 in which 1 was the lowest economic impact and 5 was the highest. The results were as follows: $1.4 \%$ rated the impact as $1 ; 8.1 \%$ rated the impact of the pandemic with a $2 ; 16.3 \%$ rated the impact with a 3 ; $35.7 \%$ rated the impact on their musical society in the pandemic with a 4 ; and $38.5 \%$ rated the impact as very high, with a 5. Therefore, $74.2 \%$ of the musical societies estimated the economic impact as being high or very high. These figures are shown below (Fig. 4).

The economic impact was $30.6 \%$ due to a decrease in members. $63 \%$ of societies lost money as a result of fewer students in their music societies. For $23.7 \%$ of these societies, the economic impact was related to payment delays with subsidies. $36.1 \%$ had contracts cancelled with town councils and festival associations, and $57.5 \%$ had their Fallas cancelled as this event could not be held. $60.7 \%$ of societies had their Moors and Christians contracts cancelled, whilst $83.1 \%$ have been affected by contract cancellations for other festivals. The economic impact has been huge in the sector, given that one of its main sources of income was eliminated, generating losses.

In the artistic dimension, we investigated how the bands were affected by the pandemic in their daily activities, i.e. concerts and street performances. The scores ranged from 1 to 5 where 1 responded to the lowest impact and 5 to the highest impact. The results were as follows: $0.5 \%$ rated the impact with a score of $1 ; 2.7 \%$ rated the impact of the pandemic with a $2 ; 12.6 \%$ indicated a score of $3 ; 29.3 \%$ of the musical societies rated the artistic impact in the pandemic with a 4 ; and $55 \%$ rated the impact with a 5 . In short, $84.3 \%$ of musical societies valued the artistic impact as high or very high. These figures are shown below (Fig. 5). 
Fig. 5 Artistic impact of the pandemic on musical societies (Source Authors' own)

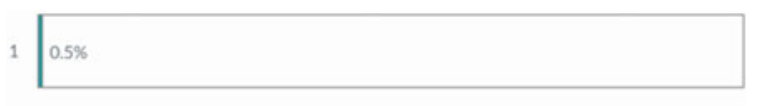

2
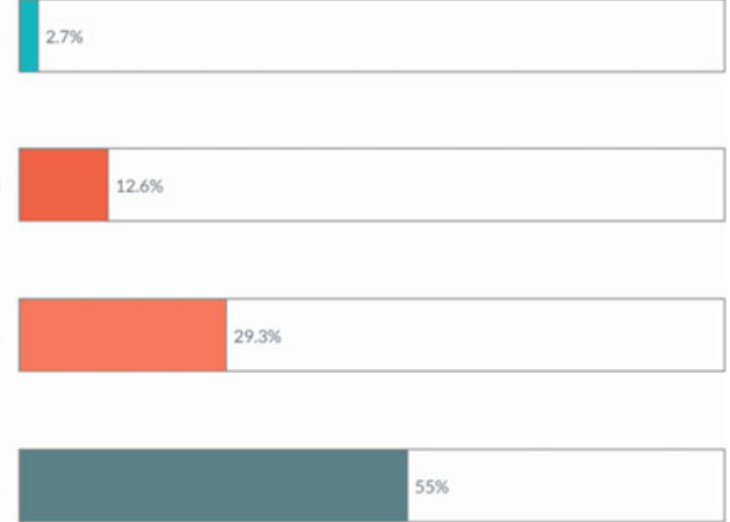

The survey was distributed in October 2020, and a question related to the current situation (at that time) of the bands was included in order to obtain a numerical result of how many of them had resumed rehearsals and performances. $90.6 \%$ had been able to resume rehearsals, with the relevant safety measures, and $58.8 \%$ had resumed their music performances, complying with the legal measures in force. $41.2 \%$ of the bands had not been able to resume their performances and were awaiting improvements in the pandemic figures (Image 7).

$70.5 \%$ of the musical groups lost band musicians. The losses of musicians were evaluated between 1 and 5, where 1 corresponded to "no musician" and 5 to "a high percentage" of musicians. The results were as follows: $31.2 \%$ rated the decrease in musicians with a $1 ; 28.8 \%$ with a $2 ; 26.5 \%$ with a $3 ; 10.7 \%$ rated the decrease with a 4 ; and $52.8 \%$ rated it as very high, with a score of 5 . These figures may correspond to temporary losses given the health situation.

The ages of the musicians who left the bands varied. Losses stood at $36.4 \%$ of the $12-18$ age group; $36.4 \%$ of the $19-25$ age group; $25.9 \%$ of the $26-35$ age group; $22.8 \%$ of the $36-45$ age group. In the $46-55$ and $56-65$ age brackets, the figures were the same, with the musical societies losing $35.2 \%$ in both cases. Finally, $34 \%$ of the musicians over 65 years of age have left the bands.

The teaching dimension centres on the music schools associated with the musical societies. The survey asked the extent to which these educational institutions had been affected by the pandemic. The respondents were given a scale of 1-5 where 1 was the lowest impact and 5 was the highest. The results were as follows: $11.9 \%$ valued the decrease in students with a score of $1 ; 17 \%$ with a score of $2 ; 25.7 \%$ with a score of $3 ; 33.9 \%$ rated the impact on their music school in the pandemic as high, with a score of 4 ; and $11.5 \%$ considered the impact as being very high, with a score of 5 . 


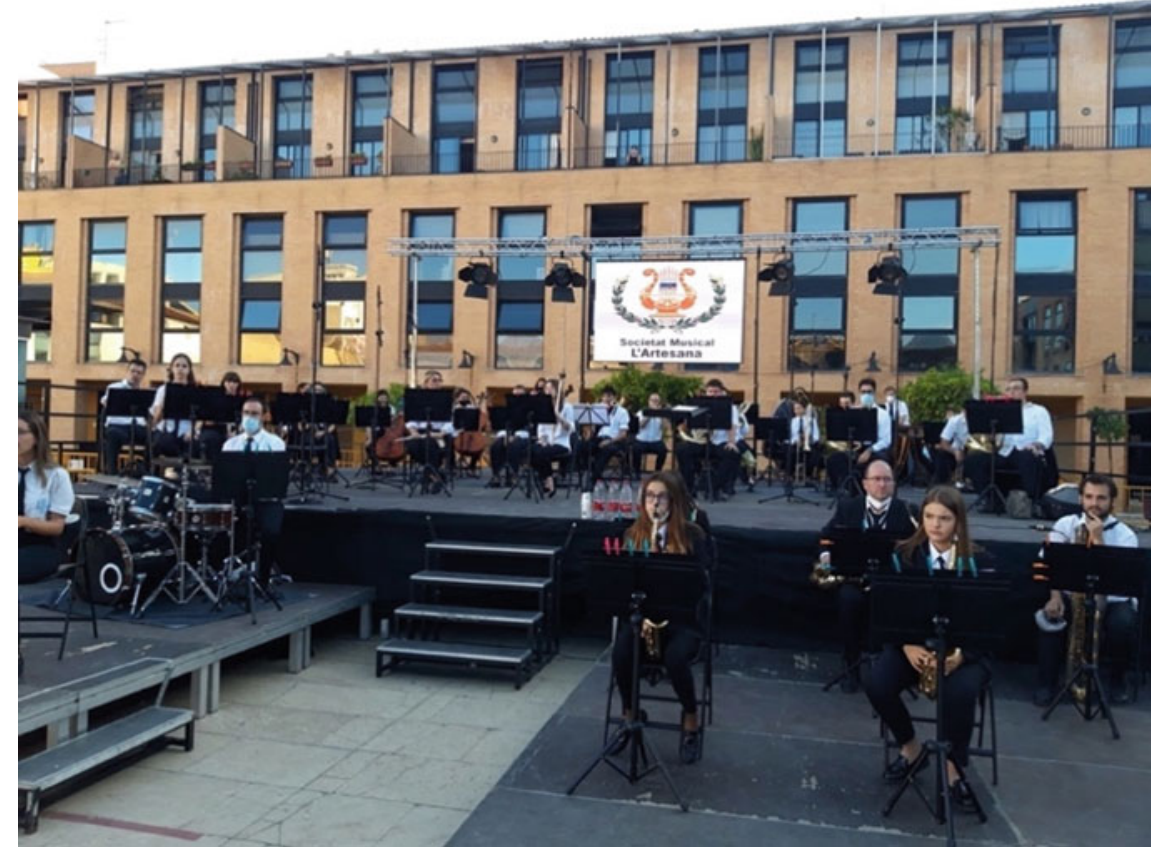

Image 7 Concert during the post-lockdown period (Source Societat Musical "L'Artesana" de Catarroja [2020])

In $92.6 \%$ of cases, classes were moved online and were streamed. They were divided into types of complexity by group subjects, such as music theory, band and choir. In these cases, an attempt was made to provide students with online classes, despite the difficulties, peculiarities and needs that each student had, and the problems caused by connection issues and different broadband speeds. These problems could not be solved by $7.4 \%$ of music schools, which had to cancel their lessons completely. Less than $8 \%$ of these music schools stated that they were waiting for the restrictions to be lifted before resuming classes (Image 8).

During this process of change, there were several working areas in which adjustments had to be made in the teaching staff's situation. 80.6\% stated that their employment status with their music schools did not change. However, classes had to be given online, which implied an extra effort and more working hours in order to change the teaching model almost overnight. Most of the schools chose this approach and it worked satisfactorily.

Other activities that took place were the music school auditions which were conducted through social networks. Some societies also carried out other types of projects related to boosting their identity, such as drawing competitions for music school students in order to support a collective sentiment among their members.

However, despite the efforts made by the teaching staff, in some cases, the musical societies stated that they had to reduce fees because the students could not use their 


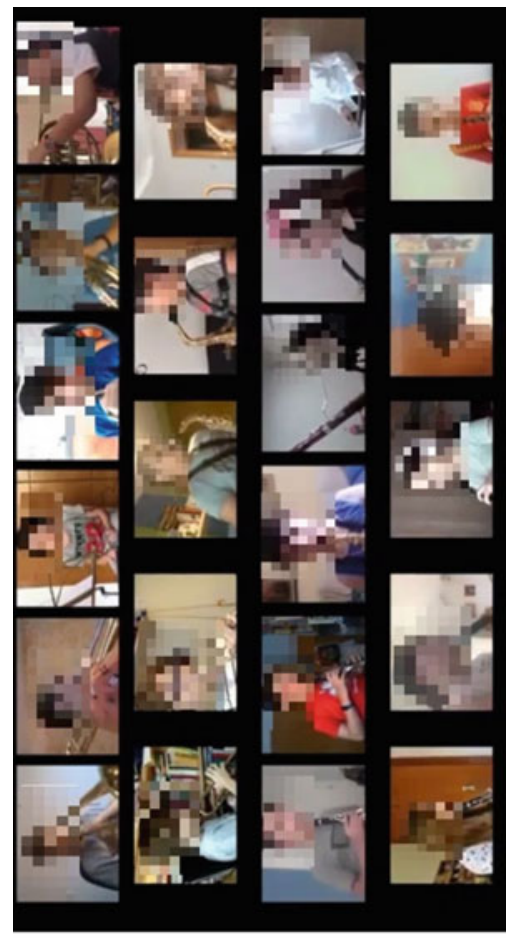

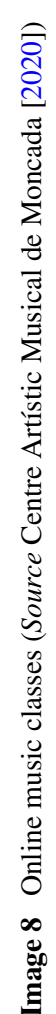

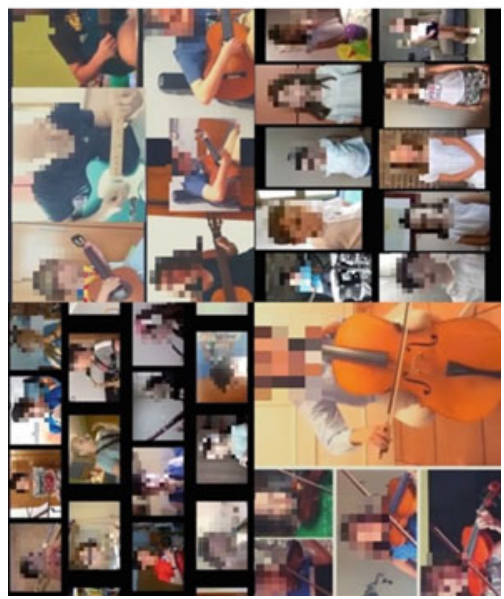


facilities, thereby reducing their sources of income. In some cases, schools had to reduce the contract hours of their teachers. Other problems included "online fatigue" of the student body as a result of so many virtual classes, due to the fact that during lockdown, primary schools also gave their classes online. Students got tired of "living online", which led to the early closure of the musical academic year.

Another situation that music schools came up against was the loss of subsidies, which meant they had to resort to applying for bank loans to maintain the teachers' payrolls. In the survey, $19.4 \%$ of societies stated that they had had to avail themselves of state aid for furloughing. Some musical societies had to terminate their teachers' contracts, especially for "musical language" and "instrumental ensemble" classes or had to make use of the Spanish Government aid system for symphonic band directors.

Regarding the loss of students in music schools, $11.1 \%$ did not suffer losses due to the exceptional situation; $38.5 \%$ lost between 1 and 10 students; $20.7 \%$ lost between 11 and 20 students; $14.9 \%$ suffered losses of between 21 and 30 students; $6.7 \%$ lost between 31 and 40 students; $2.9 \%$ lost between 41 and 50 students; $2.4 \%$ lost between $51-60$ students; $0.5 \%$ between 61 and 70 students; $0.5 \%$ suffered decreases of between 71 and 80 students; and 1.9\% stated that they had lost more than 100 students. This situation will cause in the future, a decrease of musicians in musical societies.

The ages at which the drop-out rate was higher were the 5-6 age group, with $23.36 \%$, followed by the 7-8 age group and the 3-4 age group, both with a figure of $19.96 \%$. A $15.19 \%$ drop was registered in students between 9 and 10 years of age and the figure was $14.96 \%$ in the 11 - to 12 -year-old groups. In the age of early stimulation, between 0 and 2 years, a decrease of $6.7 \%$ in the number of children was registered. This figure is low because few musical societies offer classes for this age group.

In terms of the future, $79.4 \%$ of them stated that they are now prepared for new closures in their schools, because they have developed alternative systems that have worked well, both for students and for teachers.

$86.3 \%$ of musical societies explored ways to continue their artistic activities on the Internet and considered that they were ready for possible new suspensions of rehearsals and concerts.

\section{Conclusions}

Musical societies in the Valencian Region have the ability to boost the collective spirit. They supported society in the pandemic, during lockdown and in the period of isolation, using music as a symbol of social cohesion.

However, the economic impact has been significant in the sector, since one of the main economic sources of income for the bands comes from the contracts they have to play at annual folklore festivals. These affect musicians, because they are paid activities, and also the societies, which receive a percentage of the income. 
The pandemic has also had a negative impact on the musical societies' music schools, which made huge efforts to adapt their teaching techniques to a virtual teaching environment, with all the difficulties that this entailed. Significant economic investment was also made to cater for these new needs and new way of teaching.

Throughout the pandemic, musical societies have demonstrated their power of resilience and their adaptability to difficult circumstances and have shown a commendable fighting spirit, defending the cultural, the artistic, the educational and, of course, their social and civic functions.

All of this has been reflected in the altruistic actions carried out to boost public spirits, and in the investments that the majority of musical societies did not hesitate to make in their schools, such as hiring more teachers, health monitoring services and audits to define the distance and capacity of classrooms and auditoriums, dividing class groups and reducing ratios, buying material and reinforcing cleaning and hygiene measures, including machines for purifying the air in classrooms without direct ventilation.

This series of measures should not be forgotten. They continue to be implemented thinking of the students, musicians and the different parts that make up musical societies, which are, after all, a reflection of Valencian society in an intergenerational conglomerate that can bring grandparents and grandchildren together on the same stage, sharing and conveying the same emotions.

Acknowledgements Jesús Escorihuela Castells, President of La Lírica de Silla; Francisco Piñero Sagredo, President of AM Los Silos de Burjassot; Óscar Guillem Martínez, President of SM L'Artesana de Catarroja; Federació de Societats Musicals de la Comunitat Valenciana.

\section{References}

Agrupación Musical Los Silos de Burjassot. (2020). Available via AMUSICAL.WIXSITE.COM https://amusical.wixsite.com/lossilos. Accessed 3 June 2020.

Almeria, J. F. (2014). El moviment associatiu de les societats musicals de la Comunitat Valenciana al segle XXI. Espai Despuig, 8, 35-44.

Ateneu Musical de Cullera. (2020) Historia. Available via http://www.ateneumusical.com/historia. html. Accessed 7 September 2020.

Ateneu Musical i d’Ensenyament. (2019). Banda Primitiva de Llíria, 1819-2019. Més de 200 anys de la millor Música. Ateneu Musical i dÉnsenyament. Available via BANDA PRIMITIVA.ES http://www.bandaprimitiva.es/index.php/es/. Accessed 9 October 2020.

BOE. (2020). Real Decreto 463/2020, de 14 de marzo, por el que se declara el estado de alarma para la gestión de la situación de crisis sanitaria ocasionada por el COVID-19. Available via BOE.ES https://www.boe.es/buscar/act.php?id=BOE-A-2020-3692. Accessed 23 October 2020.

Centre Artístic Musical de Moncada. (2020). Available via MUSICALMONCADA.ES https://mus icalmoncada.es. Accessed 20 June 2020.

Centro Instructivo Musical Banda de Torrefiel. (2020). Banda de Torrefiel. Available via BANDATORREFIEL.ES https://bandatorrefiel.es Accessed 19 October 2020.

III Congrés General de Societats Musicals de la Comunitat Valenciana. (2013). Resum executiu (Pau Rausell, coord.). Econcult - Universitat de València. Available via https://www.uv.es/cur segsm/PDF/IIICSMCVRE_Val_.pdf. Accessed 9 October 2020. 
Escorihuela, J., Gomis, F. X., González, X., Hernández, P., \& Soria, F. (2006). Les Bandes de música de Silla. A.M. La Lírica de Silla.

Exm. Ayuntamiento de Titaguas. (2020). Banda La Lira. Available via TITAGUAS.ES. http://www. titaguas.es/content/banda-la-lira. Accessed 17 November 2020.

Fernández Vicedo, F. J. (2010). El clarinete en España: historia y repertorio hasta el siglo XX (Tesis Doctoral). http://hdl.handle.net/10481/15084.

Ferri Chulio, A. S. (1983). Sueca, 1881-1980. Ed. Grafival S.L.

FSMCV, Federació de Societatas Musicals de la Comunitat Valenciana. (2020). El Ministerio de Cultura y Deporte inicia la tramitación para declarar Manifestación Representativa del Patrimonio Cultural Inmaterial en España las Sociedades musicales de la Comunidad de Valenciana. Available via FSMCV. ORG https://fsmcv.org/es/actualidad/noticias/el-ministeri-de-cul tura-i-esport-inicia-la-tramitacio-per-a-declarar-manifestacio-representativa-del-patrimoni-cul tural-immaterial-a-espanya-les-societats-musicals-de-la-comunitat-de-valenciana. Accessed 20 November 2020.

Generalitat Valenciana. (2018). Conselleria de Educación, Investigación, Cultura y Deporte. DECRETO 68/2018, de 25 de mayo, del Consell, por el que se declara bien de interés cultural inmaterial la tradición musical popular valenciana materializada por las socieda- des musicales de la Comunitat Valenciana. Available via DOCV.GVA.ES. http://www.dogv.gva.es/datos/2018/ 06/01/pdf/2018_5421.pdf. Accessed 9 October 2020

Infopalancia. (2016). Aniversario de la Unión Musical de Caudiel. Available via INFOPALANCIA.COM. https://www.infopalancia.com/aniversario-de-la-union-musical-decaudiel/. Accessed 9 October 2020.

Las Provincias. (2020). Las bandas de música de la Comunitat declaradas por el Gobierno como manifestación representativa del patrimonio cultural inmaterial. Available via LAS PROVINCIAS.ES https://www.lasprovincias.es/culturas/musica/bandas-musica-comunitat-202 00727163842-nt.html. Accessed 20 June 2020.

Nuestras Bandas de Música. (2020). Los músicos valencianos se preparan para dar el Do de pecho. Available via NUESTRASBANDASDEMUSICA.COM https://www.nuestrasbandasd emusica.com/noticias/noticias-nbm/organismos-instituciones/13724-los-musicos-valencianosse-preparan-para-dar-el-do-de-pecho.html. Accessed 3 November 2020.

PLÁ, C. (2020). Mascarillas para los músicos y para los instrumentos en el primer pasacalle de una banda de música. Available via NIUSDIARIO.ES https://www.niusdiario.es/cultura/esp ectaculos/mascarillas-musicos-instrumentos-primer-pasacalles-banda-musica-potries-valencia 18_2967570176.html. Accessed 20 November 2020.

Ruiz de Lihory, J. (1903). La música en Valencia. Diccionario biográfico y crítico. Establecimiento Tipográfico Doménech.

Sanimusic. (2020). Seguridad en la Música. Available via SANIMUSIC.NET https://sanimusic.net. Accessed 20 November 2020.

Societat Musical "L'Artesana" de Catarroja. (2020). Available via LARTESANA.ORG http://www. lartesana.org/societat/?lang=es. Accessed 20 June 2020.

UNESCO. (2016). Valencia Fallas festivity. Available via UNESCO.ORG. https://ich.unesco.org/ en/RL/valencia-fallas-festivity-00859?RL=00859. Accessed 20 June 2020.

Unió Músical D’Albaida “L'Aranya”. (2020). Historia. Available via http://www.umaaranya.com. Accessed 29 September 2020.

UNIÓN MUSICAL DE MURO (2020). Música de Banda a Muro 1801-2001. Available via UNIOMUSICALMURO.ORG https://uniomusicalmuro.org. Accessed 3 June 2020

Unión Musical "Sueños de Artista". (2020). U.M. "Sueños de Artista" de Almedíjar. Available vía TWITTER https://twitter.com/umsuenosartista. Accessed 3 June 2020

Valencia International Band Contest. (2020). Valencia City Council. Available via http://www.cibmvalencia.com/eng/I_historia.aspx. Accessed 20 October 2020.

Vell, F. O. (2014). Las bandas militares en la España de la Restauración (1874-1931). Nassarre, 30, 163-194. 
Open Access This chapter is licensed under the terms of the Creative Commons Attribution 4.0 International License (http://creativecommons.org/licenses/by/4.0/), which permits use, sharing, adaptation, distribution and reproduction in any medium or format, as long as you give appropriate credit to the original author(s) and the source, provide a link to the Creative Commons license and indicate if changes were made.

The images or other third party material in this chapter are included in the chapter's Creative Commons license, unless indicated otherwise in a credit line to the material. If material is not included in the chapter's Creative Commons license and your intended use is not permitted by statutory regulation or exceeds the permitted use, you will need to obtain permission directly from the copyright holder.

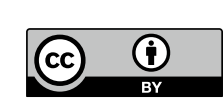

